\title{
Selection and integration of environmental impacts in the Danish transport infrastructure assessment process
}

\author{
Olesen, I. M.; Barfod, Michael Bruhn
}

Published in:

International Journal of Sustainable Development and World Ecology

Link to article, DOI:

$10.1080 / 13504509.2018 .1536682$

Publication date:

2019

Document Version

Peer reviewed version

Link back to DTU Orbit

Citation (APA):

Olesen, I. M., \& Barfod, M. B. (2019). Selection and integration of environmental impacts in the Danish transport infrastructure assessment process. International Journal of Sustainable Development and World Ecology, 26(3), 191-209. https://doi.org/10.1080/13504509.2018.1536682

\section{General rights}

Copyright and moral rights for the publications made accessible in the public portal are retained by the authors and/or other copyright owners and it is a condition of accessing publications that users recognise and abide by the legal requirements associated with these rights.

- Users may download and print one copy of any publication from the public portal for the purpose of private study or research.

- You may not further distribute the material or use it for any profit-making activity or commercial gain

- You may freely distribute the URL identifying the publication in the public portal 


\title{
Selection and Integration of Environmental Impacts in the Danish Transport Infrastructure Assessment Process
}

\author{
Ida Marie Olesen ${ }^{\mathrm{a}}$ and Michael Bruhn Barfod ${ }^{\mathrm{a} *}$ \\ ${ }^{a}$ Department of Management Engineering, Technical University of Denmark, Kongens Lyngby, \\ Denmark
}

*Corresponding author: Department of Management Engineering, Produktionstorvet 424, DK-2800 Kongens Lyngby, Denmark. Telephone: +45 4525 1540, e-mail: mbba@dtu.dk

\begin{abstract}
Transport projects have numerous consequences for the environment, society and economy, and thus an EU Directive has stated a number of impacts that need to be assessed prior to any major intervention. This paper is set in a Danish context where the EU requirements have been adopted in the Environmental Impact Assessment (EIA) regulation along with national requirements. In recent years, however, the EIAs have been criticized for an inconsistent inclusion of impacts and unclear assessment process. A selection of EIAs are for this reason reviewed and compared to the EU Directive and corresponding works in Sweden and the UK to identify potential opportunities for improvements. From the literature study, an overview table with all potential relevant impacts for transport projects is set up to assist the EIA process. For the sake of simplicity and transparency, the impacts selected from this table should, however, be further reduced in number to ensure that only the most important impacts are included in the process. To further increase simplicity and transparency in the EIA process, a novel framework for assessing different types of impacts is proposed. In this framework, a comprehensive decision support tool involving stakeholders is in focus. The framework is supplemented with a procedure for generating objectives and presenting results in an appropriate way to the many stakeholders involved. The impacts overview table and the assessment techniques are applied to a case study to illustrate the process, and finally conclusions and perspectives for future work within the field are set out.
\end{abstract}

Keywords: Environment Impact Assessment (EIA), Stakeholder involvement, Multi-Criteria Decision Analysis, Analytic Hierarchy Process (AHP), Transport assessment 


\section{Introduction}

Member countries in the European Union (EU) are by a number of regulations required to perform comprehensive examinations of the consequences of infrastructure projects (Pearce et al., 2006). Environmental Impact Assessments (EIA) are governed by the EU Directive "On the assessment of the effects of certain public and private projects on the environment" from 1985 (EU, 2014). The directive states which project types that need to undergo an EIA, and it consists of a list of environmental impacts and additional information that the EIA is to clarify (EU, 2014). The directive is adopted in the Danish EIA regulation as well as in the Danish law for planning (DME, 2015). However, Danish EIAs have recently received criticism of the numerous appraisals performed for each project, which are very costly and do not seem to be used in the way it is intended in the decision making process (The Engineer, 2013). A part of this criticism may stem from the fact that the EIA guidelines are not that detailed from European level, and it is unclear how it should be used in the decision making process. Here the appraisal seem to be a tool for qualifying the basis for decision rather than for choosing the most environmental friendly option. To change this perception and use of the EIAs there is a need for more transparency in the process. In this respect, the often-varying impact assessment part is a key issue.

Extensive research has been conducted within the area of indicators and impacts for assessing transport infrastructure projects (see e.g. Joumard and Nicolas (2010), Jourmard and Gudmundsson (2010), Zietsmann et al. (2011) and Cornet et al. (2018)). Several frameworks for environmental and social indicator sets have also been developed to accommodate this need (see e.g. Cornet (2016), Marsden et al. (2006), Niemeijer (2002), Niemeijer and Groot (2008), or NCHOD (2005)). However, most of the research considers the issues on a theoretical and general level, and overall it has shown that it is not possible to develop one single list of impacts or indicators to consider when assessing transport projects. Instead, specific conditions in the single 
countries need to be taken into account when developing such a list. This paper makes an attempt to develop an operational and comprehensive list of impacts for the use in the Danish transport sector in order to make the assessment process more consistent and transparent.

Thus, the purpose of this paper is to review the current Danish approach for transport project assessment and develop a comprehensive list of impacts to be considered in the assessment process. Moreover, the paper examines the transparency of the EIA by clarifying the content of the reports. The paper takes its basis in the Danish sector, but makes use of input from similar processes in the normally comparable countries: Sweden and the UK. The approach is illustrated using an infrastructure case study.

The structure of the paper is as follows. After this introduction, Section 2 reviews the impacts assessed in the Danish EIA process and the assessment techniques used. Following this, the main differences between the Danish and corresponding Swedish and UK procedures are outlined to identify possible improvements in the Danish process. Section 3 develops a revised framework for the Danish EIA process, and in Section 4 the suggested techniques and improvement are applied to a case study. Section 5 discusses the strengths and weaknesses of the proposed framework, and finally Section 6 presents the conclusions and perspectives for further work within the field.

\section{Impacts assessed in the Danish EIA}

There are some differences between the aforementioned EU Directive on EIA and the contents of the Danish regulation. These will be outlined in the following.

Annex 4 in the EU Directive and in the Danish regulation describes the impacts that need to be included in the EIA. An outline of these impacts is depicted in Figure 1. The yellow colour depicts requirements stated in both the EU Directive and the Danish regulations, and the orange colour depicts requirements only stated in the Danish regulation. Note that all requirements are 
listed in Annex 4 of the directive with no or little explanation (and no subdivision such as in the figure).

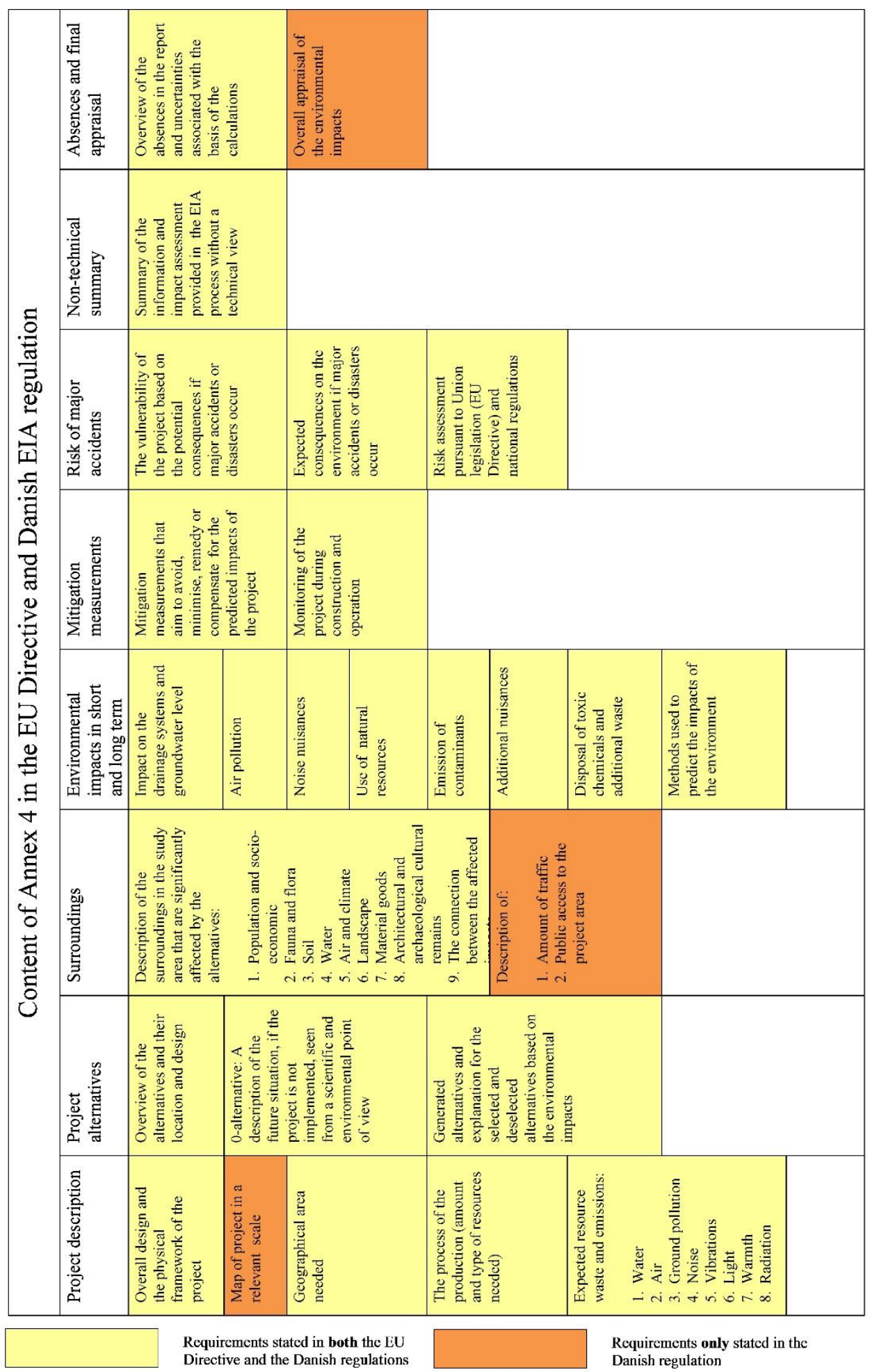


[Figure 1. Content of the EU EIA regulation and Danish EIA regulation, adapted from (DME, 2015)]

As shown in Figure 1, extra requirements has been added to the content of the EIA in Denmark. E.g., the Danish regulation states that the "amount of traffic" (which apart from congestion can lead to emission of noise, air pollution, greenhouse gasses, accidents etc.) must be determined and described, the public access to the project area must be clarified, and the project area must be illustrated on a map. Furthermore, the Danish regulation states that an overall appraisal of the environmental impacts should be specified. However, the type of environmental impact assessment or the degree of detail in the appraisal is not described in the regulation. Thus, it is not clear whether the regulation alludes to the assessment of individual impacts or to assessments where the environmental impacts are compared in an overall assessment of the environmental consequences.

The analysis in this section is based on a review of the 10 most recent EIA reports concerning road, rail and public transport projects in Denmark. The reports are listed below.

- New Fixed Link, Frederikssund (DRD, 2010a)

- New Fixed Link, Aalborg (DRD, 2011)

- New Fixed Link, Storstrøm (DRD, 2014a)

- By-pass road, Ribe (DRD, 2015)

- By-pass road, Næstved (DRD, 2010b)

- By-pass road, Haderup (DRD, 2014b)

- $\quad$ Light-rail, Ring corridor 3 (DMT, 2015)

- Copenhagen - Ringsted High-speed Railway (DTA, 2009) 
- Electrification and upgrading of speed limits, North of Køge-Næstved (RND and DNA, 2014)

- $\quad$ Metro City Ring (CC and MF, 2006)

\subsection{Structure and content}

The content and structure of the EIA is put into a scheme, see Figure 3, that presents the information and impacts contained in the studied reports. Information marked in yellow are included in all studied reports, and information marked in orange are only included in some reports. Information not required by the Danish EIA regulation (but still assessed in some reports) is marked with an arrow.

The assessment of the impacts is to some extent subjective as the formulation of the requirements in the EU Directive and the Danish regulations only are vaguely stated. E.g., the Danish regulation demands a description of the "amount of traffic", but it does not state whether this includes calculations of capacity and traffic safety. From the review of the EIA reports, it is assumed that the phrase "amount of traffic" includes all directly related traffic impacts such as capacity and traffic forecasts, whereas impacts that occur in consequence of traffic (e.g. traffic safety, punctuality, temporary traffic constructions) are not covered.

From Figure 2 it is evident that the Danish EIAs are structured very randomly and the report structure are very different between authorities. The top authority of EIA is the Danish Ministry of Transport, but the practising authority depends on the intervention at hand. The Danish Road Directorate (DRD) is the authority if the project involves government owned roads, Rail Net Denmark carries out studies for Danish Rail projects, and affected municipalities are authorities for minor transport projects. E.g., EIAs conducted by the Danish Road Directorate usually consist of four different papers: a summary report, an environmental appraisal, a land use analysis, and a site 
analysis together with a number of background notes. Reports conducted by the Rail Net Denmark consist of one final report and several technical notes specifying consequences on groundwater, soil, noise, vibrations, geographical area, natural resources, etc.

\begin{tabular}{|c|c|c|c|c|c|c|c|c|}
\hline $\begin{array}{c}\text { Non-technical } \\
\text { summary }\end{array}$ & Background & $\begin{array}{l}\text { Project description } \\
\text { and alternatives }\end{array}$ & $\begin{array}{l}\text { Principles and } \\
\text { methods }\end{array}$ & $\begin{array}{c}\text { Traffic } \\
\text { consequences }\end{array}$ & $\begin{array}{l}\text { Environmental } \\
\text { impacts }\end{array}$ & $\begin{array}{l}\text { Geographic } \\
\text { A rea }\end{array}$ & Socio-economic & Absences \\
\hline \multirow{19}{*}{$\begin{array}{l}\text { Summary of the } \\
\text { information and } \\
\text { impactassessment } \\
\text { provided in the } \\
\text { EIA process } \\
\text { without a } \\
\text { technical view }\end{array}$} & $\begin{array}{l}\text { Existing } \\
\text { circumstances }\end{array}$ & \multirow{6}{*}{$\begin{array}{l}\text { Rough assessment and } \\
\text { studies of alternatives: } \\
\\
\text { 1. Idea generating } \\
\text { process and pre- } \\
\text { liminary consultation } \\
\text { 2. Stepwise selection of } \\
\text { altematives without } \\
\text { regard to } \\
\text { environmental } \\
\text { impacts, traffic, } \\
\text { economic and } \\
\text { technical factors } \\
\text { 3. Reason for deselection } \\
\text { of alternatives }\end{array}$} & \multirow{4}{*}{$\begin{array}{l}\text { Methods and } \\
\text { models for } \\
\text { calculations of } \\
\text { traffic and capacity } \\
\text { on roads and } \\
\text { railways }\end{array}$} & \multirow{5}{*}{$\begin{array}{l}\text { Traffic calculations } \\
\text { in the construction } \\
\text { and operating } \\
\text { period on roads and } \\
\text { railways (traffic } \\
\text { forecasts, amount } \\
\text { of } \\
\text { traffic/passengers, } \\
\text { travel time savings) }\end{array}$} & $\begin{array}{l}\text { Landscape and visual } \\
\text { conditions }\end{array}$ & \multirow{2}{*}{$\begin{array}{l}\text { Properties affected } \\
\text { permanently or } \\
\text { temporary }\end{array}$} & \multirow{6}{*}{$\begin{array}{l}\text { Construction costs } \\
\text { 1. Preliminary } \\
\text { examination of the } \\
\text { construction costs } \\
\text { 2. Environmental } \\
\text { costs } \\
\text { 3. Additional options } \\
\text { added to the } \\
\text { project } \\
\text { 4. EU financial } \\
\text { support }\end{array}$} & \multirow{4}{*}{$\begin{array}{l}\text { Uncertainties } \\
\text { associated } \\
\text { with the } \\
\text { basis of the } \\
\text { calculations }\end{array}$} \\
\hline & \multirow{2}{*}{$\begin{array}{l}\text { Purpose of the } \\
\text { EIA studies and } \\
\text { assessment }\end{array}$} & & & & Noise & & & \\
\hline & & & & & Vibrations & \multirow{4}{*}{$\begin{array}{l}\text { 1. Changes access } \\
\text { to propertie } \\
\text { 2. Expropriation } \\
\text { 3. Division of } \\
\text { properties - new } \\
\text { plan for land } \\
\text { distribution } \\
\text { 4. Restrictive } \\
\text { covenant }\end{array}$} & & \\
\hline & \multirow{2}{*}{$\begin{array}{l}\text { The process of } \\
\text { the public } \\
\text { consultations } \\
\text { accomplished }\end{array}$} & & & & Preservations & & & \\
\hline & & & $\begin{array}{l}\text { Methods and } \\
\text { models for } \\
\text { calculations of the } \\
\text { noise level and }\end{array}$ & & $\begin{array}{l}\text { Soil conditions, } \\
\text { amount of soil } \\
\text { needed and polluted } \\
\text { soil }\end{array}$ & & & $\begin{array}{l}\text { Lack of } \\
\text { knowledge }\end{array}$ \\
\hline & \multirow{2}{*}{$\begin{array}{l}\text { The } \\
\text { remaining/ future } \\
\text { process of the } \\
\text { project }\end{array}$} & & & Capacity & $\begin{array}{l}\text { Archaeological } \\
\text { heritage and cultural } \\
\text { heritage }\end{array}$ & & & \\
\hline & & $\begin{array}{l}\text { Physical lay out and } \\
\text { design on the alternatives } \\
\text { considered }\end{array}$ & \multirow{2}{*}{$\begin{array}{l}\text { Estimation and } \\
\text { calculations of } \\
\text { environmental } \\
\text { impact } \\
\text { consequences }\end{array}$} & $\begin{array}{l}\text { Traffic safety, } \\
\text { accidents and } \\
\text { recorded safety }\end{array}$ & $\begin{array}{l}\text { Outdoor and } \\
\text { recreational activities }\end{array}$ & \multirow{3}{*}{$\begin{array}{l}\text { Temporary } \\
\text { workplaces: } \\
\text { 1. Access roads } \\
\text { 2. Storing areas } \\
\text { and construction } \\
\text { areas } \\
\text { 3. Harbours needed } \\
\text { for material } \\
\text { shipping }\end{array}$} & \multirow{3}{*}{$\begin{array}{l}\text { - Socio-economic } \\
\text { results: } \\
\text { 1. Net present value } \\
\text { (NPV) } \\
\text { 2. Internal rate of } \\
\text { return (IRR) } \\
\text { 3. Net present value } \\
\text { per public } \\
\text { invested DKK } \\
\text { (NCR) }\end{array}$} & \\
\hline & $\begin{array}{l}\text { Historical } \\
\text { review }\end{array}$ & $\begin{array}{l}\text { - Speed limitations and } \\
\text { speed considerations }\end{array}$ & & \multirow{2}{*}{$\begin{array}{l}\text { Temporary } \\
\text { traffic flow for } \\
\text { traffic on roads and } \\
\text { railways }\end{array}$} & $\begin{array}{l}\text { Air pollution and } \\
\text { climate }\end{array}$ & & & \\
\hline & $\begin{array}{l}\text { The value and } \\
\text { importance of the } \\
\text { current } \\
\text { intervention at } \\
\text { hand }\end{array}$ & $\begin{array}{l}\text { Baseline studies ( } 0 \text { - } \\
\text { alternative): description } \\
\text { of the future situation if } \\
\text { the intervention is not } \\
\text { implemented }\end{array}$ & $\begin{array}{l}\text { Methods to } \\
\text { assess the } \\
\text { magnitude of the } \\
\text { impact }\end{array}$ & & $\begin{array}{l}\text { Groundwater, } \\
\text { drainage and } \\
\text { wetlands }\end{array}$ & & & \\
\hline & \multirow{4}{*}{$\begin{array}{l}\text { Previous } \\
\text { decision } \\
\text { processes, } \\
\text { studies, reports, } \\
\text { plans, committee } \\
\text { appointments, } \\
\text { consultations and } \\
\text { rulings }\end{array}$} & \multirow{3}{*}{$\begin{array}{l}\text { Adjustment to the } \\
\text { additional transport } \\
\text { infrastructure systems }\end{array}$} & & \multirow{2}{*}{$\begin{array}{l}\text { Traffic-related } \\
\text { coherences }\end{array}$} & Light & & \multirow{3}{*}{$\begin{array}{l}\text { The robustness of } \\
\text { the analy ses }\end{array}$} & \\
\hline & & & & & $\begin{array}{l}\text { Raw materials, } \\
\text { energy and waste }\end{array}$ & & & \\
\hline & & & & \multirow{2}{*}{$\begin{array}{l}\text { Additional traffic } \\
\text { effects e.g. safety } \\
\text { for ship traffic }\end{array}$} & Flora and fauna & & & \\
\hline & & $\begin{array}{l}\text { Extra options and } \\
\text { opportunity for change }\end{array}$ & & & Natura 2000-areas & & $\begin{array}{l}\text { Description of the } \\
\text { non-monetary } \\
\text { impacts }\end{array}$ & \\
\hline & & \multirow{2}{*}{$\begin{array}{l}\text { Demolition of existing } \\
\text { infrastructure e.g. brid- } \\
\text { ges. Strategies, methods } \\
\text { and reestablishment of } \\
\text { the transport systems and } \\
\text { surroundings }\end{array}$} & & $\begin{array}{l}\text { Punctuality, } \\
\text { timetables and } \\
\text { correspondences }\end{array}$ & $\begin{array}{l}\text { Population and } \\
\text { socio-economy: } \\
\text { businesses, health, } \\
\text { human and society }\end{array}$ & & $\begin{array}{l}\text { Summary } \\
\text { assessment of the } \\
\text { altematives }\end{array}$ & \\
\hline & & & & & $\begin{array}{l}\text { Mitigation } \\
\text { measurements and } \\
\text { monitoring }\end{array}$ & & & \\
\hline & & $\begin{array}{l}\text { Attached activities that } \\
\text { relate to the project }\end{array}$ & & & $\begin{array}{l}\text { Geology (stability of } \\
\text { ground) }\end{array}$ & & & \\
\hline & & - Time schedule & & & Magnetic fields & & & \\
\hline & & - Completion of project: & & & Smell and dust & & & \\
\hline & & $\begin{array}{l}\text { steps in the construction } \\
\text { peniod and building } \\
\text { methods for construction } \\
\text { of bridges or tunnels }\end{array}$ & & & $\begin{array}{l}\text { Environmental } \\
\text { considerations at the } \\
\text { end of the } \\
\text { construction period. }\end{array}$ & & & \\
\hline
\end{tabular}

[Figure 2. Information and impacts contained in Danish EIA reports]

Presentation of traffic impacts in the EIA is not required according to the EU Directive. Yet, these impacts are usually well described in Denmark where EIA reports usually include traffic forecasts, capacity calculations, safety, additional precautions needed within the study area, and an examination of the traffic flow during the construction period. 


\subsection{The methodologies applied}

The impacts assessed in the EIA are divided into monetary and non-monetary assessable impacts, and for each impact, the assessment methodology is noted in Table 1. In general, several methods (e.g. mapping, calculations, and overview tables) are used to assess consequences for the monetary impacts, and the findings are often well described and illustrated in the reports. The non-monetary impacts on the other hand, are usually only described qualitatively and supported by maps. The absence of overview tables and figures illustrating, summarising or underlining the main consequences results in that the essence of the impact often disappears in the amount of prose.

[Table 1. Methods used to assess monetary and non-monetary impacts in the EIA]

\begin{tabular}{|c|c|}
\hline Monetary impacts & Methods used for assessment \\
\hline Noise & Terminology, calculations, modelling and mapping \\
\hline Air and climate & Terminology, calculations and modelling \\
\hline Raw materials needed & $\begin{array}{l}\text { Qualitative descriptions and establishment of the need. The impact is usually included } \\
\text { in the construction costs }\end{array}$ \\
\hline Soil & $\begin{array}{l}\text { Qualitative descriptions and appraisal of impact using mapping. Relocation of soil is } \\
\text { usually included in the construction costs }\end{array}$ \\
\hline Geographical area needed & $\begin{array}{l}\text { Terminology and mapping. Expropriation is usually included in the construction } \\
\text { costs. }\end{array}$ \\
\hline Traffic & $\begin{array}{l}\text { Calculations, modelling and mapping e.g. of traffic growth, travel time savings, } \\
\text { amount of traffic. Calculations concerning traffic accidents and capacity }\end{array}$ \\
\hline Construction costs & $\begin{array}{l}\text { Qualitative descriptions and presentation of benefits, costs and investment criteria e.g. } \\
\text { NPV and IRR in an overview table }\end{array}$ \\
\hline Non-monetary impacts & Methods used for assessment \\
\hline Landscape & Qualitative descriptions (and sometimes mapping and overview tables) \\
\hline Vibrations & Qualitative descriptions \\
\hline Preservations & Qualitative descriptions (and sometimes mapping) \\
\hline
\end{tabular}




\begin{tabular}{|l|l|}
\hline $\begin{array}{l}\text { Archaeological heritage and } \\
\text { cultural heritage }\end{array}$ & Qualitative descriptions (and sometimes mapping) \\
\hline $\begin{array}{l}\text { Outdoor and recreational } \\
\text { activities }\end{array}$ & Terminology, qualitative descriptions (and sometimes overview tables) \\
\hline Water & Qualitative descriptions (and sometimes mapping) \\
\hline Light & Qualitative descriptions \\
\hline Flora and fauna & Terminology, qualitative descriptions (and sometimes mapping) \\
\hline Natura 2000-areas & $\begin{array}{l}\text { Qualitative descriptions (and sometimes mapping). The impact is also assessed under } \\
\text { the Danish Habitat Directive, Article 6. }\end{array}$ \\
\hline Population & Qualitative descriptions \\
\hline Geology & Qualitative descriptions \\
\hline Magnetic fields & Qualitative descriptions \\
\hline Smell and dust & Qualitative descriptions \\
\hline
\end{tabular}

A specific terminology is used to assess certain impacts. The terminology is used to specify the degree of disturbance, importance of the impact based on the size of the damaged area, the probability of the occurrence of the impact consequences and the duration of the impact. The terminology used in EIA reports is shown in Table 2. However, the exact formulation of the terminology can vary a bit from the different authorities.

[Table 2. Terminology used to assess certain impacts]

\begin{tabular}{llll}
\hline Degree of disturbance & Importance & Probability & Duration \\
\hline Significant & National & High $(>75 \%)$ & Permanent $(>5$ years $)$ \\
Moderate & Regional & Middle $(25-75 \%)$ & Temporary (1-5 years) \\
Small & Local & Low $(<25 \%)$ & Short term (<1 year) \\
None & Cross-border & &
\end{tabular}

Not important 
The terminology is used to classify the impact and underline the importance of the specific impacts. Even though the intention is good it usually turns out as being meaningless as the terminologies is only mentioned in the text and thereby lost in the amount of prose. Only three of the studied reports are using overview tables to highlight the terminology, see Figure 3.

\begin{tabular}{lcc}
\hline Danish EIA reports & Terminology & Overview table \\
\hline New Fixed Link, Frederikssund & $\checkmark$ & $\checkmark$ \\
New Fixed Link, Aalborg & $\checkmark$ & \\
New Fixed Link, Storstrøm & $\checkmark$ & $\checkmark$ \\
By-pass road, Ribe & $\checkmark$ & \\
By-pass road, Næstved & $\checkmark$ & $\checkmark$ \\
By-pass road, Haderup & $\checkmark$ \\
Light-rail, Ring corridor 3 & $\checkmark$ \\
Copenhagen - Ringsted Railway & $\checkmark$ \\
Electrification, Køge - Næstved & $\checkmark$ \\
Metro City Ring & $\checkmark$
\end{tabular}

[Figure 3. EIA reports using terminology and overview tables]

In overview tables, the terminology is sometimes converted to colour scales to illustrate the expected impacts and to provide comparability of the different alternatives. Figure 4 is an example of an overview table from DRD (2010a) where the degree of disturbance is converted to a four-step colour signature. The landscape and soil impacts are divided into sub-categories, and the degree of 
disturbance is evaluated for each sub-category and for each alternative (see upper line of Figure 4) in both the construction period and the operating period.

\begin{tabular}{|c|c|c|c|c|c|c|c|c|c|c|c|c|}
\hline Impact on the landscape and soil & \multicolumn{7}{|c|}{ Overall appraisal } \\
\hline Construction period & N1a & N1b & NIc & N2a & N2b & S1 & S2a & S2b & S3a & S3b & S6 \\
\hline Landscape east of the fjord & & & & & & & & & & & \\
\hline Landscape near the coast of the fjord & & & & & & & & & & & \\
\hline Landscape west of the fjord & & & & & & & & & & & \\
\hline Geological areas of interest & & & & & & & & & & & \\
\hline Soil conditions & & & & & & & & & & & \\
\hline Operating period & & & & & & & & & & & \\
\hline Landscape east of the fjord & & & & & & & & & & & \\
\hline Landscape near the coast of the fjord & & & & & & & & & & & & \\
\hline Landscape west of the fjord & & & & & & & & & & & \\
\hline Geological areas of interest & & & & & & & & & & & \\
\hline Soil conditions & & & & & & & & & & \\
\hline Signature: & & & & & & & & & & \\
\hline
\end{tabular}

[Figure 4. Example of overview consequence table for assessment of alternatives in Danish EIA reports, adopted from DRD (2010a)]

Overview tables are useful to summarise the consequences of each impact, but they can also be useful to compare all alternatives and impacts and thereby act as a summary of the assessments. However, none of the studied EIA reports are using overview tables to compare all alternatives and impacts. The impacts are only described and assessed separately. Actually, only a few of the reports conclude on the findings and highlight the overall advantages and disadvantages of the alternatives. This can be a huge disadvantage for decision makers who often do not have time to read the entire report but instead relies on a summary.

\subsection{Main differences compared to Swedish and UK EIAs}

The main differences between the impacts assessed in Denmark and the corresponding content in the United Kingdom (UK) and Sweden are presented in the following section. The review of the 
UK process is based on the assessment of the High Speed Rail 2 (HS2) project (Booz \& Co. and Temple, 2011; HS2 Ltd., 2013), which is a project that has undergone extensive assessment and an enormous amount of public available publications concerning the project exist (Cornet et al., 2018). The Swedish content is based on the following four recent EIA reports concerning rail and road projects:

- $\quad$ Road 222, Skurubron (MN and SC, 2014)

- $\quad$ Road 23, Älmhult-Ljungstrop and Ljungstrop-Mölleryd (MÄ and KC, 2011)

- Railway, Mälar-track (STA, 2013)

- Railway, Ostlänken (SRA, 2009)

\subsubsection{The Swedish content}

The Swedish government has just as Denmark applied additional regulations for their EIAs compared to the EU Directive. The results of the review of the content in the Swedish reports are presented in Figure 5. Note that the colours of the areas have the same meaning as for Figure 2. The limited number of orange coloured areas indicates that the reports contain the same impacts and are structured identically even though they are produced by different authorities. The few alterations just point out differences in project size and the variations in impacts on the environment. The homogeneity entails a degree of transparency, and the findings become more verifiable and auditable. It is in this way easier to obtain the needed information and to understand the problem at hand. 


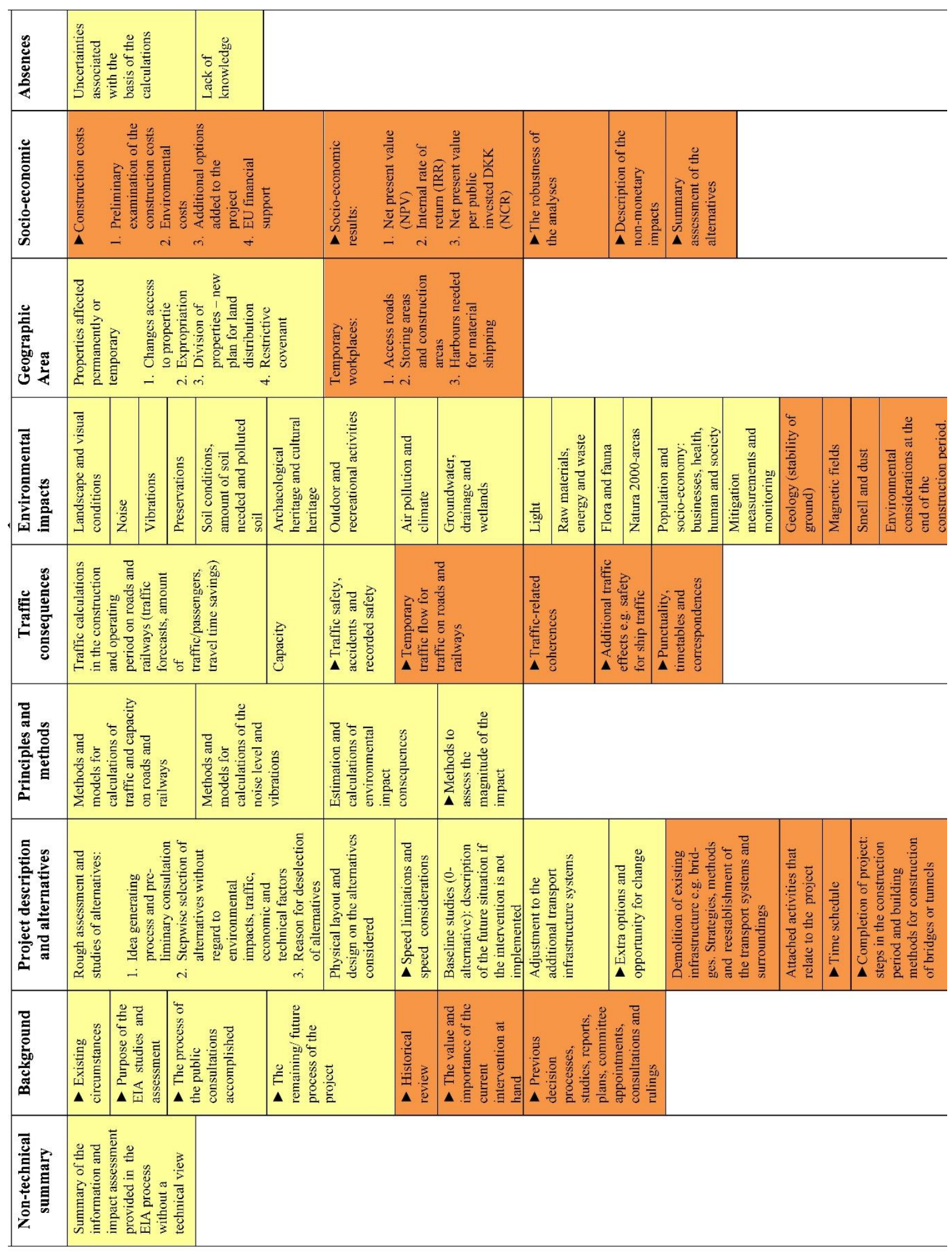

[Figure 5. Information and impacts contained in Swedish EIAs] 
In the Swedish EIA procedure the relevant environmental impacts are described systematically in the following order:

(1) General knowledge of the specific impacts and prerequisites.

(2) The findings of impact consequences in both the construction and operation period. All findings are summarised by using illustrations, see Figure 6.

(3) Different possible mitigation measures (for the construction and operating period).

\begin{tabular}{|l|l|l|l|l|l|l|}
\hline & \multicolumn{2}{|c|}{ Norrköping - Bäckeby } & \multicolumn{2}{c|}{ Bäckeby-Linkjöping } \\
\hline & $\begin{array}{c}\text { Red } \\
\text { alternative }\end{array}$ & $\begin{array}{c}\text { Blue } \\
\text { alternative }\end{array}$ & $\begin{array}{c}\text { Green } \\
\text { alternative }\end{array}$ & $\begin{array}{c}\text { Red } \\
\text { alternative }\end{array}$ & $\begin{array}{c}\text { Blue } \\
\text { alternative }\end{array}$ & $\begin{array}{c}\text { Green } \\
\text { alternative }\end{array}$ \\
\hline Landscape & & & & & & \\
\hline Culture & & & & & & \\
\hline Nature & & & & & & \\
\hline Outdoor and recreational areas & & & & & & \\
\hline Health & & & & & & \\
\hline Nature resources & & & & & & \\
\hline Risk and safety & & & & & \\
\hline Construction time \\
Small consequences: \\
Soderate consequences:
\end{tabular}

[Figure 6. Example of overview consequence table for assessment of alternatives in Swedish EIAs, adopted from SRA (2009)]

The impacts assessed in Danish and Swedish EIAs are almost identical. However, transport impacts are described significantly more detailed in Denmark than in Sweden. This level of detail is not irrelevant as future transport developments can influence the environmental state, health and well-being of wildlife as well as human beings dramatically. Therefore, a thorough detailed examination of all impacts is very important. However, the Danish process can learn from the Swedish and the extensive use of consequence tables, such as the one depicted in Figure 6, which provides the decision maker with a visual summary of the consequences of the impacts. 


\subsubsection{Structural techniques used in the UK}

In the UK, intervention-specific objectives are stated early in the process. The objectives are identified based on stakeholder involvement, and the formulation of objectives is based on existing local, regional and national visions. Moreover, the objectives are continually developed as additional data and information is collected. The objectives are used to generate and improve alternatives, and only those alternatives that can comply with the objectives, alone or in combination with other alternatives, can be selected. The generated and selected alternatives can vary in size, technology, costs, transport mode, etc. Furthermore, alternatives are deselected based on "show-stoppers", risk assessment, costs and objectives (TAG, 2014). In TAG (2014), "showstoppers" are defined as any physical, legal and institutional constraints that may limit the potential transport options available.

All potential relevant impacts are described in the reports. This means that the list of impacts assessed usually is long, and summary tables are frequently included to underline and illustrate the main conclusions. Moreover, the tables are used to compare the impacts for the different alternatives, and to ensure that the reader (e.g. the decision-maker or stakeholder) can obtain the needed information without being overloaded with information (TAG, 2014; GOV, 2013). E.g. for each alternative in an assessment, a table containing the impacts is produced. The alternatives are divided into intervals, and for each interval the impacts are given a score on a 5 point scale indicating the consequences on e.g. the environment, see Figure 7.

The purpose of such an overview table is to illustrate the total consequences of the alternatives, to enhance hazards and to provide comparability between the alternatives. Just as in Sweden, the many guidelines of EIA in the UK entail that the methods are used systematically and homogenously. The output of reports in the UK is transparent even though containing a high level of information as numerous impacts are assessed at a relative detailed level. 


\begin{tabular}{cl}
\hline Evaluation & Description \\
\hline-- & Highly unsupportive of objective \\
- & Unsupportive of objective \\
\hline - & Neutral \\
+ & Supportive of objective \\
++ & Highly supportive of objective \\
\hline U & Unknown at this stage of the design process \\
\hline N/A & Not applicable \\
\hline
\end{tabular}

[Figure 7. Key to evaluation adopted from Booz \& Co. and Temple (2011)]

\section{Proposed framework for the Danish EIA process}

In the following section, the best methods and principles for use in the Danish EIA are presented based on the review of Sweden, UK and additional literature (i.e. Niemeijer (2002), NCHOD (2005), Marsden et al. (2006), Niemeijer and Groot (2008), Joumard and Nicolas (2010), Jourmard and Gudmundsson (2010), Zietsmann et al. (2011), Cornet (2016) and Cornet et al. (2018)). In this connection an overview table concerning potential impacts relevant for Danish transport projects is developed.

\subsection{Objectives and alternatives}

A clear set of intervention-specific objectives should be identified and formulated in the early stage of the project process to obtain a transparent EIA. In accordance with the AHP technique a three level hierarchy of objectives (see Table 3) can assist and support the clarification of the rationality of the intervention and provide a framework for the evaluation and appraisal process (see also TAG (2014)). The high-level objectives are used to generate a range of alternatives. Ideally, the generated alternatives should represent different solutions that vary in scale, technologies, costs, transport 
modes, etc. The intermediate-level objectives are used to specify the objectives that should be met by the expected impacts of the project, and the low-level objectives are the operational objectives that ensures that the intermediate objectives are met.

\begin{tabular}{lll}
\hline $\begin{array}{l}\text { High-level } \\
\text { (strategic outcomes) }\end{array}$ & $\begin{array}{l}\text { Intermediate-level } \\
\text { (specific objectives) }\end{array}$ & Low-level \\
\hline $\begin{array}{lll}\text { Strategic outcomes that express } \\
\text { the desired end state and reflect }\end{array}$ & $\begin{array}{l}\text { Specific objectives that should be } \\
\text { achieved for a number of impacts }\end{array}$ & Operational objectives that represent \\
the aims and ambitions for the & that are expected to occur due to & necessary for the intermediate \\
$\begin{array}{l}\text { local, regional, national (and } \\
\text { international) area and }\end{array}$ & the project. These objectives need & objectives to be achieved. These \\
population. These are wide and & outcomes to be realised, both in & indicators and they should be as \\
qualitatively formulated. & the long and short run. & SMART ${ }^{1}$ as possible.
\end{tabular}

[Table 3. Hierarchy of objectives (TAG, 2014)]

The start-phase of the project should include a session, where alternatives that alone cannot comply with the high-level objective are combined with other alternatives. After this alternatives that clearly cannot comply with the high-level objectives, alone or in combination with other alternatives, are discarded. The selection of alternatives should include relevant stakeholders to ensure consensus (Barfod and Salling, 2015). Thus, a thorough stakeholder analysis should be

${ }^{1}$ The SMART model is a tool used to formulate objectives to ensure that these are realistic and ambitious. A SMART objective is: Specific, Measurable, Attainable, Realistic and Time defined (Gudmundsson et al., 2015) 
conducted prior to the start-phase in order to identify who should be included in the further process. This will be the responsibility of the managing authority of the EIA.

Furthermore, the selection of alternatives should be based on both socio-economic analyses and environmental appraisals.

\subsection{Identifying important impacts}

The objectives and the selected alternatives should be used to select a range of impacts relevant for the project. The review of Danish EIAs has revealed a 'usual pallet' of environmental impacts even though these impacts do not seem significantly important to the specific intervention at hand.

An overview table containing a list of all potential relevant impacts for transport projects can be used to identify the project specific relevant impacts. A proposal for such an impact overview table for Danish transport projects is shown in Table 4 (Olesen, 2016). The table is based on the review of impacts assessed in Denmark, Sweden, the UK as well as the aforementioned additional literature. However, in an initial phase of a project it can be difficult to predict all relevant impacts, and therefore, only potential important impacts are identified. As the project information level increases and the intermediate-level and low-level objectives are formulated, the selected impacts can be reviewed, and only the substantially important impacts included further on in the assessment. To select the impacts, an Environmental Risk Assessment (ERA) tool can be used to identify potential hazards. All impacts are listed in an event or decision tree and each impact is assigned a "score of relevance" (SR). The SR reflects the probability of a particular hazard to occur, and impacts with high SR should be examined in detail. When assigning mitigation measurements to the current impacts they might need extra attention and impacts with a low SR should probably not be included in the final assessment (Morris and Therivel, 2001). 
[Table 4. Overview table used for generating impacts (Olesen, 2016)]

\begin{tabular}{|c|c|c|}
\hline Landscape & Soil & Nature \\
\hline Physically-related & Geology and geomorphology & Fauna \\
\hline Geology & Surface geology $*$ & Lost or ruined habitats \\
\hline Terrain conditions & Underground geology $*$ & Breed disturbance (e.g. birds) \\
\hline \multirow[t]{2}{*}{ Landform and ecology } & The immaterial history of Earth $*$ & Direct deceases (e.g. on road) \\
\hline & Topography (terrain) $*$ & Pollution (incl. eutrophication) * \\
\hline Human-related & Vibrations * & Microorganisms underground $*$ \\
\hline History of landscape & & Fauna on bottom of e.g. streams \\
\hline Land use (incl. expropriation) & Soil conditions & and lakes \\
\hline Buildings and habitations & Polluted soil and other & \\
\hline Cultural means & implications of the soil & Flora \\
\hline Preservations & Amount of soil (mass balance) & $\begin{array}{l}\text { Natura 2000-areas } \\
\text { Felling or pruning of e.g. trees }\end{array}$ \\
\hline Aesthetic-related & & Vegetation in e.g. streams, lakes \\
\hline Visual conditions $*$ & & Ecological links and ecosystem * \\
\hline Sensuous feelings $*$ & & Distinctive valuable natural resorts \\
\hline $\begin{array}{l}\text { Material assets and } \\
\text { archaeological heritage }\end{array}$ & Air pollution and climate & Water \\
\hline Archeologic & Air pollution & Surface water \\
\hline Historical buildings and sites & Sulphur dioxide $\left(\mathrm{SO}_{2}\right) *$ & Streams, lakes and other wetlands $*$ \\
\hline Ancient remains & Particulates (dust, $\mathrm{PM}_{10}, \mathrm{PM}_{2.5}$ ) * & Drainage of surface areas \\
\hline Historical areas $*$ & Nitrogen oxides $\left(\mathrm{NO}_{\mathrm{x}}: \mathrm{NO}, \mathrm{NO}_{2}\right) *$ & Hydraulic systems * \\
\hline Archaeological findings in the & Carbon monoxide $(\mathrm{CO}) *$ & Recreational value * \\
\hline study area & $\begin{array}{l}\text { Volatile organic compounds } \\
\text { (VOCs), e.g. benzene * }\end{array}$ & $\begin{array}{l}\text { Infiltration and water flow at land * } \\
\text { Pollution of surface water } *\end{array}$ \\
\hline Materials and sensuous feelings & Toxic organic micropollutants & Humane related \\
\hline Administration of natural resources & (TOMPs), e.g. PAHs, PCBs * & \\
\hline Reutilisation of materials & & \\
\hline
\end{tabular}




\begin{tabular}{|c|c|c|}
\hline Waste & Toxic metals, e.g. lead $*$ & Changes in cost line and the water \\
\hline Magnetic fields & Toxic chemicals, e.g. chlorine $*$ & depth \\
\hline Light & Ozone $\left(\mathrm{O}_{3}\right) *$ & Establishment of storm water \\
\hline Air, smell and dust & Ionising radiation (radionuclides)* & reservoirs \\
\hline \multicolumn{3}{|l|}{ Energy use } \\
\hline Noise (incl. compound noise) $*$ & Climate & Groundwater \\
\hline Pressure on the labour market $*$ & Greenhouse gasses * & Water quality * \\
\hline \multirow{7}{*}{ Delivery of materials } & Changes in rainfall and seasons & Lowering of groundwater level * \\
\hline & Alterations to the airflow * & Changes in flow and direction \\
\hline & Addition of moisture from indus- & Protection of aquifers \\
\hline & trial cooling towers, reservoirs $*$ & Influence from buildings $*$ \\
\hline & Reduction in sunlight & Drainage of wetlands \\
\hline & Ponding of cold air behind & Conditions for water catchment in \\
\hline & physical barriers * & the study area \\
\hline
\end{tabular}

\section{Population}

\begin{tabular}{lll}
\hline Economic impacts & Social impacts & Transport \\
Local and non-local employment & Changes in population size & Capacity and delay \\
Characteristics of employment * & Changes in other population & Number of tours \\
Labour supply & characteristics * & Speed \\
Local and state finances & Small urban communities & Accidents \\
House prices & Settlement patterns $*$ & Pedestrian and cycle flow \\
Agriculture & Distribution between private and & Accessibility \\
Tourism & public sectors & Location and type of car parking \\
& Health services; social support * & Barrier effects \\
& Social problems $*$ & Freight transport \\
& Local activities/services & Public transport
\end{tabular}


The impacts marked with an asterisk can be interpreted in more than one way. A more detailed description of these impacts are provided in Appendix A.

\subsection{Assessment techniques}

In Denmark, monetary impacts are assessed using a CBA whereas non-monetary impacts are mainly assessed qualitatively. To ensure a broader assessment of non-monetary impacts, a wider range of comprehensive decision tools can be used to support the decision-making process. The use of multi-criteria decision analysis (MCDA) have previously been suggested to support this process, see e.g. Barfod and Salling (2015), Wright et al. (2009), Tsamboulas (2003) and Vreeker (2002). The Analytic Hierarchy Process (AHP) by Saaty (1977) is a comprehensive tool for MCDA based on stakeholder involvement. In the AHP tool, qualitative assessments for both monetary and nonmonetary impacts are performed by structuring, comparing and weighting all impacts in a pairwise way to arrive at a final set of scores (total scores) for the alternatives (Belton and Stewart, 2002). Unlike the in CBA, the comparisons are performed according to the subjective preferences of the participants of the assessment group. The inclusive nature of the AHP techniques is found to be very useful for decision making processes in the public sector which often involves a long list of conflicting criteria as well as stakeholders influencing the process. For this reason and its versatility, AHP has been chosen for use in the present study.

All relevant impacts (direct/primary impacts, indirect/secondary impacts as well as accumulated impacts that occur over time) should be assessed. To obtain the maximum value of performing the AHP, the assessments should be based on discussions in groups of stakeholders, experts, etc. (Barfod, 2018; Barfod and Salling, 2015). This part of the assessment can with benefit be structured using a workshop-concept where the participants (stakeholders) under the guidance of 
an impartial facilitator can go through the different steps of appraisal. It can be difficult for stakeholders to agree on the weights of the impacts, and therefore, different overall stakeholder profiles can be generated to represent preferences relating to e.g. sustainability, environment, economy, urban development and social conditions (Cornet et al., 2018) However, it is important that all profiles are challenged to ensure useful discussions about the relative importance of the impacts (Barfod, 2012; Leleur, 2012).

Due to the inherited subjectivity of the MCDA the results are associated with uncertainties. The uncertainties should be actively managed and measured using risk assessments and sensitivity analyses concerning both the monetary impacts testing for optimism bias (Salling, 2008) and nonmonetary impacts using ERA (Olesen, 2016; Morris and Therivel, 2001).

Depending on the type of study, the output should be reported in different ways to different audiences. In general, the output should be presented in a level of detail that enables different parties to contribute to the debate and make their decisions in a fully informed manner. All conclusions should be presented in a clear and logical manner without over-burdening the reader with information (TAG, 2014). A short and concise EIA report (incl. CBA, MCDA and ERA) should be presented to the decision-makers, whereas public servants should have a more detailed version of the report.

\section{The case study}

This section presents the case study used to exemplify the proposed framework. The case concerns the overall infrastructure in the Greater Copenhagen area in Denmark, which consists of five major transport corridors that provide accessibility to central Copenhagen, see Figure 8. 


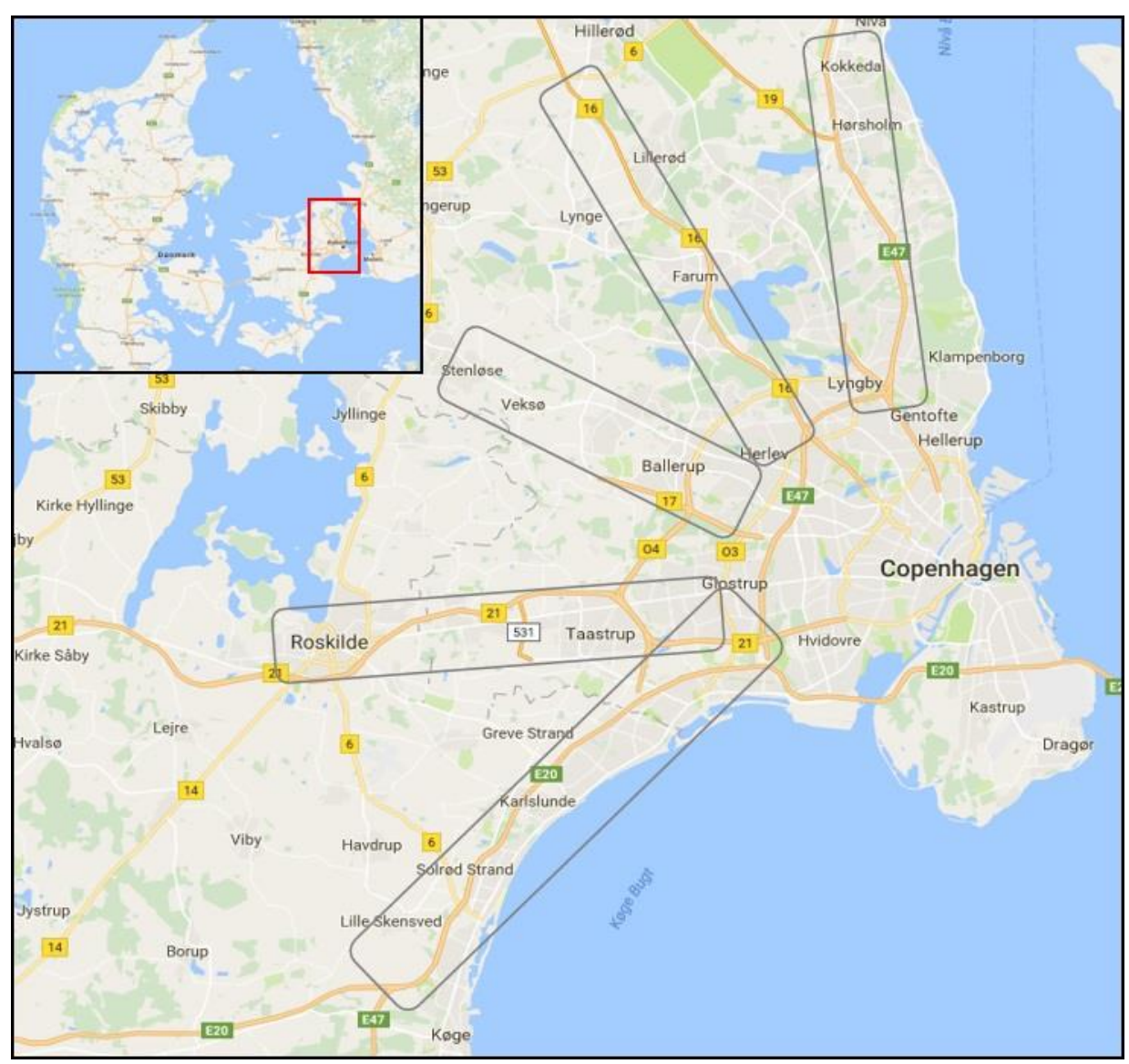

[Figure 8. Location of the Greater Copenhagen area and the five corridors]

The corridors are heavily congested as the need for travelling along and across the corridors has increased significantly during the recent decade. The case concerns the examination of alternatives for dealing with the issue (Sund \& Bælt A/S, 2007; Nielsen, 2011; DRD, 2012; 2013a; 2016). The alternatives consist of new road and rail corridors and alternatives upgrading or replacing the existing infrastructure corridors. Objectives are formulated in order to generate alternatives, and ERA and the overview table (see Table 4) is used to identify the relevant impacts. Finally, all alternatives and impacts are assessed in a comparative analysis using the AHP tool including CBA results. 


\subsection{Objectives and alternatives}

A three-level set of objectives has been formulated and prioritised by the authors, see Table 5 . The prioritisation is based on the hypothesis that the current political majority consensus in Denmark in 2018 prioritises traffic and economic related objectives ${ }^{2}$.

[Table 5. Objectives at three levels]

\begin{tabular}{|c|c|c|}
\hline $\begin{array}{l}\text { High-level } \\
\text { (strategic outcomes) }\end{array}$ & $\begin{array}{l}\text { Intermediate-level } \\
\text { (specific objectives) }\end{array}$ & $\begin{array}{l}\text { Low-level } \\
\text { (operative objectives) }\end{array}$ \\
\hline 1. Better connection between & 1. Create better flow on the major & 1. Increase the average speed on major \\
\hline major transport corridors & transport corridors and connecting & transport corridors during peak hours \\
\hline 2. Redirect heavy traffic around & roads & to the travelling speed after project \\
\hline city centres & 2. Improve the economic benefits & opening. \\
\hline 3. Achieve a positive socio- & for commuters & 2. Reduce the peak hours (where the \\
\hline economic return & 3. Improve the economic benefits & average speed is below $\mathrm{V} \mathrm{km} / \mathrm{h}$ ) with a \\
\hline 4. Create growth in the Greater & for business travellers & $\begin{array}{l}\text { minimum of } \mathrm{W} \text { minutes per weekday } \\
\text { at specific major transport corridors }\end{array}$ \\
\hline Copenhagen area and better & 4. Avoid noise nuisances in urban & \\
\hline \multirow[t]{5}{*}{ conditions for businesses. } & areas & $\begin{array}{l}\text { 3. Achieve a socio-economic } \mathrm{BCR}^{3} \\
\text { value greater than } 1 \text {, a NPV above } 0\end{array}$ \\
\hline & 5. Preservation of important & and an IRR higher than the discount \\
\hline & historical buildings and areas & rate \\
\hline & 6. Preservation of recreational & \\
\hline & areas & \\
\hline
\end{tabular}

${ }^{2}$ The Danish government anno 2018 represents the right-wing political spectrum and have at several occasions given indications of this strategy

${ }^{3}$ Benefit cost rate (BCR) is a socio-economic performance indicator 
4. Reduce the everyday travel time for commuters and business travellers with $\mathrm{X} \%$ in the year after opening.

5. Achieve Y \% lower noise levels than the established noise limits for the construction period ${ }^{4}$.

6. Preservation of $\mathrm{Z} \%$ of the most important historic buildings and areas.

7. Preserve or reconstruct all recreational areas of importance (if the users/locals want them preserved or reconstructed)

The high-level objectives are used to generate a range of 13 alternatives, see Table 6 . The authors have generated the alternatives based on the aforementioned existing literature on the issue to exemplify the process, and the alternatives include different modes, infrastructures, regulations, pricings and other ways of influencing travel behaviour.

${ }^{4}$ Noise limits for road (rail) traffic: recreational areas in open land $=53(59) \mathrm{dB}$, recreational areas in (or near) urban areas $=58(64) \mathrm{dB}$, residential areas $=58(64) \mathrm{dB}$, public use $=59(64) \mathrm{dB}$, liberal industry $=$ $63(69) \mathrm{dB}$. 
[Table 6. Generated alternatives]

\begin{tabular}{|c|c|c|c|c|}
\hline No. & Name & Mode & Comment & $\begin{array}{l}\text { Achievable } \\
\text { objectives }\end{array}$ \\
\hline 1 & Highway M5 & Road & 4-lane motorway or expressway in ring corridor 5 & All \\
\hline 2 & Highway M51/2 & Road & 4-lane motorway or expressway in ring corridor $5 \frac{1}{2}$ & All \\
\hline 3 & Highway M6 & Road & Upgrade of existing $6^{\text {th }}$ ring corridor: Rute $6 /$ Rute 53 & Some \\
\hline 4 & Highway 4 & Road & Extension of capacity of the existing Highway 4 & All \\
\hline 5 & ITS on Highway 3 & Road & $\begin{array}{l}\text { More effective utilisation of Highway } 3 \text { by } \\
\text { implementing ITS and perform minor constructions }\end{array}$ & Some \\
\hline 6 & $\begin{array}{l}\text { Pointwise upgrades at } \\
\text { Rute 6/Rute } 53\end{array}$ & Road & $\begin{array}{l}\text { Upgrade of Rute } 6 / \text { Rute } 53 \text { by performing pointwise } \\
\text { constructions e.g. a new bypass east of Hillerød }\end{array}$ & Some \\
\hline 7 & $\begin{array}{l}\text { Construction of a } \\
\text { section, Highway M5 }\end{array}$ & Road & $\begin{array}{l}\text { Construction of a section of Highway M5 e.g. } \\
\text { between Roskilde finger and Frederikssund finger }\end{array}$ & Some \\
\hline 8 & Railway in corridor 5 & Rail & Double railway track in ring corridor 5 & All \\
\hline 9 & Light rail in M5 & Public & Light rail or Bus Rapid Transit (BRT) in corridor 5 & Some \\
\hline 10 & $\begin{array}{l}\text { Main road and light } \\
\text { rail in M5 }\end{array}$ & Road/ & $\begin{array}{l}\text { 2-lane main road or expressway in ring corridor } 5 \\
\text { combined with light rail or BRT }\end{array}$ & All/Some \\
\hline 11 & ITS, access roads & Road & $\begin{array}{l}\text { ITS solution with dynamic lanes (more lanes into } \\
\text { Copenhagen (Cph) in the morning, opposite in the } \\
\text { afternoon) on some main access-roads to } \mathrm{Cph}\end{array}$ & Some \\
\hline 12 & Harbour tunnel & Road & $\begin{array}{l}\text { A 4-lane road bypass east of Copenhagen in a } \\
\text { harbour tunnel }\end{array}$ & All/Some \\
\hline 13 & Shipping & Ship & $\begin{array}{l}\text { Shipping of freight (incl. the lorry) between Northern } \\
\text { Germany and Southern Sweden }\end{array}$ & Some \\
\hline
\end{tabular}

The alternatives are scrutinized as described in Section 3 and reduced to a set that fulfils the high-level objectives. The alternatives selected for further assessment are presented in Table 7 and illustrated in Figure 9. 
[Table 7. Selected alternatives]

\begin{tabular}{llll}
\hline No. & Name & Mode & Comment \\
\hline 1 & Highway M5 & Road & 4-lane motorway or expressway in ring corridor 5 \\
2 & Highway M51/2 & Road & 4-lane motorway or expressway in ring corridor 51/2 \\
3 & Highway 4 & Road & Extension of capacity of the existing Highway 4 \\
4 & Combined ITS solution & Road & More effective utilisation of Highway M3 by implementing ITS and \\
& & & perform minor constructions combined with introducing dynamic roads \\
& & & on Køge Bugt highway (a main access motorway to Copenhagen) \\
5 & Railway in corridor 5 & Rail & Double railway track in ring corridor 5 \\
& Harbour tunnel & Road & A 4-lane road bypass east of Copenhagen in a harbour tunnel \\
\hline
\end{tabular}




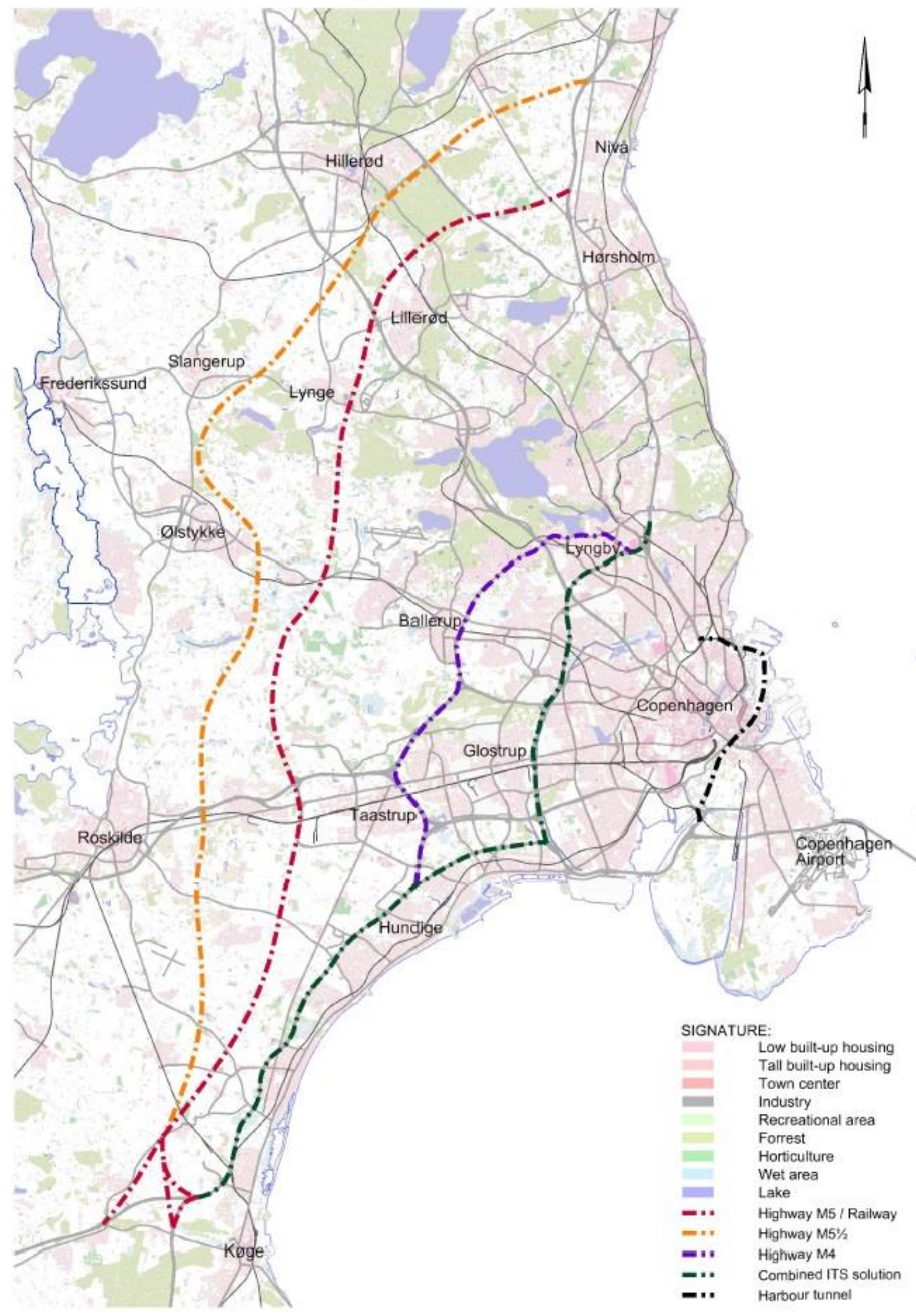

[Figure 9. Selected corridor alternatives] 


\subsection{Selection of impacts}

The impacts presented in Table 4 are systematically reviewed, and the ones relevant for the selected alternatives are grouped in Table 8. In order to be considered relevant for further analysis the selected impacts must be operational in this preliminary stage, and the impacts must all represent issues affected by the respective alternatives. If not, they will not produce a useful input for the comparative analysis and the selection of the best performing alternative, i.e. they will be irrelevant.

[Table 8. Selected relevant impacts from Table 3]

\begin{tabular}{|c|c|c|}
\hline Landscape & Soil & Nature \\
\hline Human-related & Geology and geomorphology & Fauna \\
\hline Land use (incl. expropriation) & Vibrations & Lost or ruined habitats \\
\hline \multicolumn{3}{|l|}{ Cultural means } \\
\hline \multirow{2}{*}{ Aesthetic-related } & Soil conditions & Flora \\
\hline & Amount of soil (mass balance) & Natura 2000-areas \\
\hline \multicolumn{3}{|l|}{ Visual conditions } \\
\hline $\begin{array}{l}\text { Material assets and } \\
\text { archaeological heritage }\end{array}$ & Air pollution and climate & Water \\
\hline Archeologic & Air pollution & Surface water \\
\hline \multirow[t]{2}{*}{ Historical buildings and sites } & Sulphur dioxide $\left(\mathrm{SO}_{2}\right)$ & Streams, lakes and other wetlands \\
\hline & Particulates (dust, $\mathrm{PM}_{10}, \mathrm{PM}_{2.5}$ ) & \\
\hline Materials and sensuous feelings & Nitrogen oxides (NOx: $\mathrm{NO}, \mathrm{NO}_{2}$ ) & Groundwater \\
\hline \multirow[t]{3}{*}{ Noise (incl. compound noise) } & Carbon monoxide (CO) & Lowering of groundwater level \\
\hline & Volatile organic compounds & \\
\hline & (VOCs), e.g. benzene & \\
\hline
\end{tabular}

\section{Climate}

Greenhouse gasses 


\begin{tabular}{lll}
\hline Population & & \\
\hline Economic impacts & Social impacts & Transport \\
Local and state finances & Small urban communities & Capacity \\
Agriculture & Outdoor and recreational & Delay \\
& activities & Accessibility \\
& Barrier effects \\
& Freight transport \\
& Public transport \\
\hline
\end{tabular}

To simplify the process in this case example, only transport-related impacts that can be assessed without a traffic model have been selected. This also means that impacts such as "Pedestrian and cycle flow" and "Location and type of car parking" are considered irrelevant as they do not contribute to the segregation of the alternatives. The selection can e.g. be done using ERA as noted in Section 3.

\subsection{Assessment of main impacts}

The assessments of the impacts are to be presented in an illustrative and transparent way, and to condense the information the assessments are summarised in two overview tables - one for the monetary impacts (Table 12) and one for the non-monetary impacts (Table 13). The impacts are evaluated using the scale in Figure 10.

\begin{tabular}{cl}
\hline Evaluation & Description \\
\hline-- & Major deterioration of impact/high costs \\
- & Deterioration of impact/minor costs \\
\hline & Neutral \\
+ & Improvement of impacts/minor benefits \\
++ & Major improvements of impacts/major benefits \\
$\mathrm{U}$ & Unknown at this stage of the design process \\
\hline
\end{tabular}

[Figure 10. Key to evaluation of impacts] 


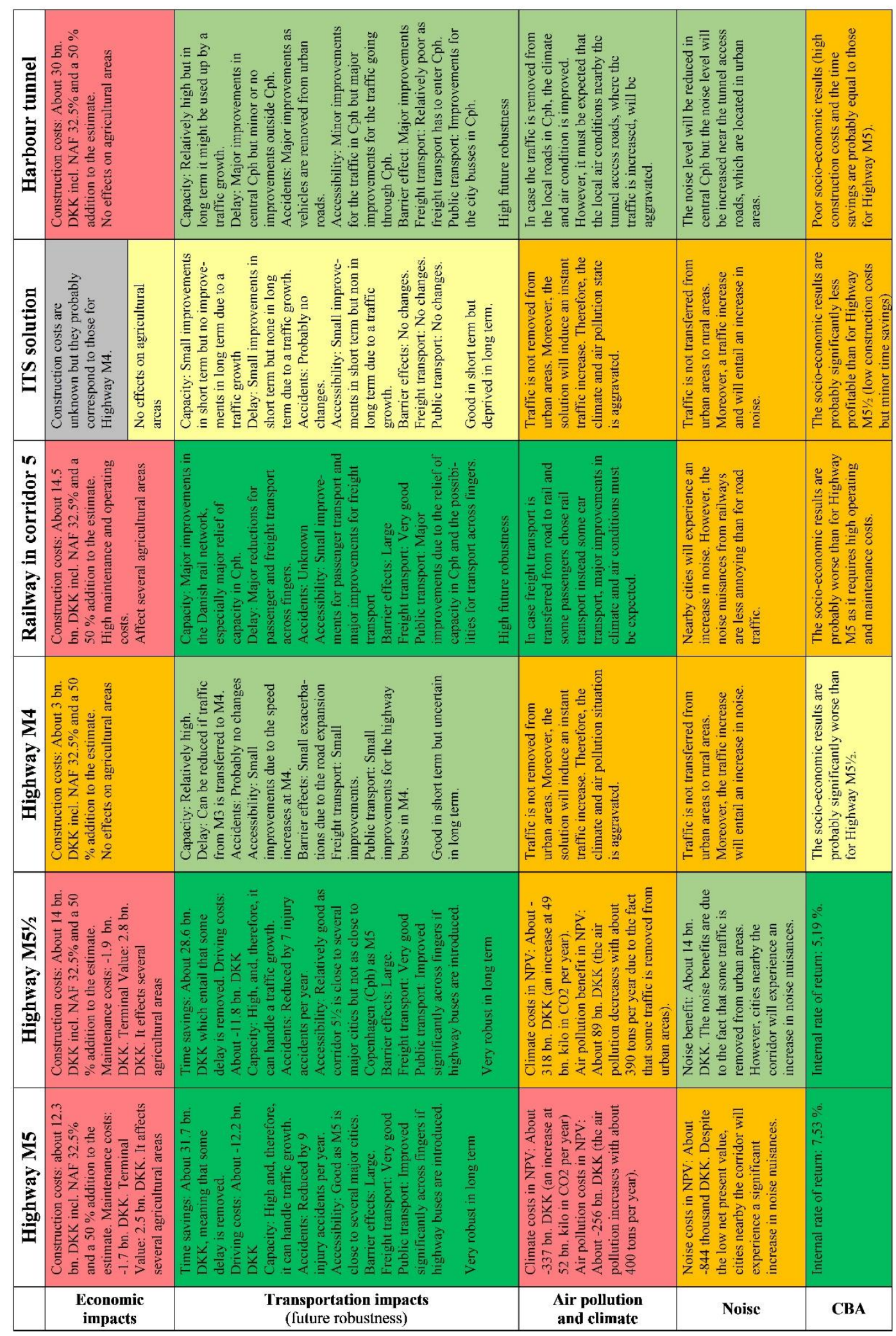

[Figure 11. Summary Appraisal Table for monetary impacts] 


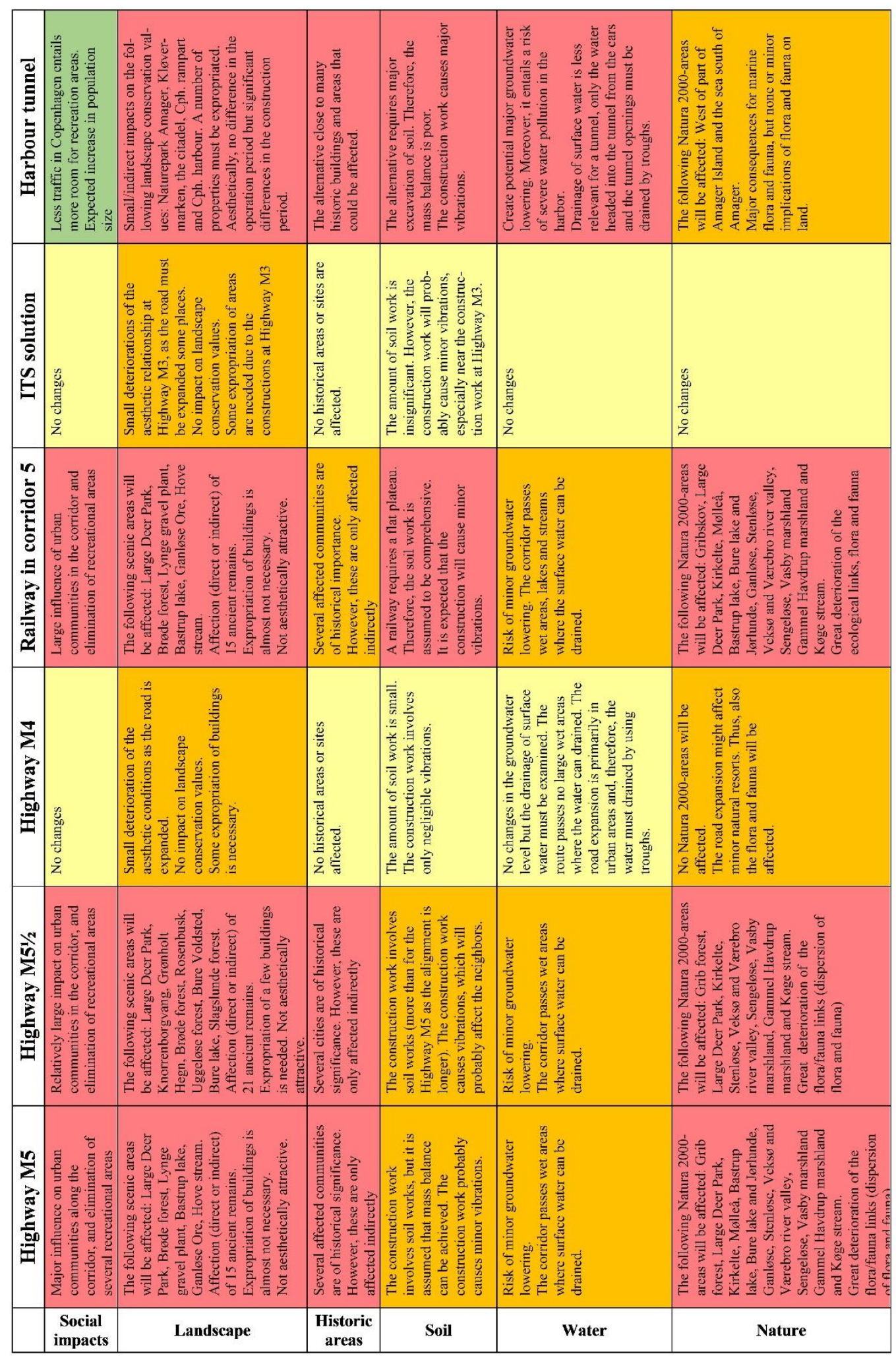

[Figure 12. Summary Appraisal Table for non-monetary impacts] 
The overview tables indicate that Highway M5 and Highway M51/2 require high costs and that the alternatives entail deterioration of the local air condition and the climate, and the social impacts, landscape, historical areas and sites, soil and water will be affected negatively. On the other hand, the monetary impact overview table evidently shows an increase in transportation, which entails socio-economic feasibility. Almost the same pattern is seen for the Railway in corridor 5; however, this alternative entails improvements in the local air condition and climate state, and due to the high maintenance and operating costs, the socio-economic results are not as beneficial as for Highway M5 and M51/2.

The Combined ITS solution and Highway M4 have low construction costs and they only entail minor impacts on the environment. Conversely, they do not improve transportation in the region significantly and the socio-economic feasibility is uncertain.

The Harbour Tunnel is highly expensive and the surrounding landscape, historical areas and sites, soil and water will be affected negatively. The transportation impacts, noise, air and climate state in Greater Copenhagen areas are improved slightly. Thus, these impacts result in poor socioeconomic results.

\subsection{Comparative analysis}

The six alternatives are compared using the AHP to obtain an overall ranking. In this case-study, the comparisons have been performed by the authors as it only serves as a demonstration of the assessment tool and how it can provide transparency during the process. Ideally, the comparison of alternatives and assigning of weights to impacts should be performed by stakeholders and experts. The imitation of different stakeholder profiles is obtained by weighting the impacts using three different profiles: political, local and sustainability desires, see Table 9. 
The political profile sympathises with the prioritisation of the objectives (see Section 4.1), meaning that direct impacts, such as accessibility and delay, are the most important. However, the financial impacts are also important. Expropriation, which is covered by the Landscape impact, requires financial resources and is therefore important from a political point of view. The environmental and social impacts are least important in this profile.

In the sustainability profile, the weightings are based on the nested model of sustainability (Daly 1990; Costanza et al. 1997). Therefore, environmental impacts (Nature, Air pollution and climate, and Water) are given the highest weights followed by the social impacts (Material assets and archaeological heritage - due to the noise aspect - Landscape, Social impacts and Transportation). The economic impacts (Soil and Economic impacts) are then assigned the lowest weights (Pryn et al., 2015).

The local profile favours impacts that are important for local property owners and local politicians. Nature, Social impacts and Landscape are the impacts given the highest weights, followed by transport impacts, as the purpose of the project is to improve accessibly to the local districts.

[Table 9. Weights for criteria, sub-criteria and sub-sub-criteria. Weights for three different profiles: Criteria weights indicated with bold fonts, sub-criteria weights indicated with normal fonts, and sub-sub-criteria weights indicated with italic fonts. Note that the weights are normalised to sum to 1.]

\begin{tabular}{lllc}
\hline & Political & Sustainability & Local \\
\hline Landscape & $\mathbf{0 . 1 1}$ & $\mathbf{0 . 0 5 9}$ & $\mathbf{0 . 1 5 5}$ \\
Humane related & 0.875 & 0.8 & 0.5 \\
- History of landscape and settlements & 0.1 & 0.8 & 0.5 \\
- Cultural means and land use & 0.9 & 0.2 & 0.5 \\
Aesthetic related & 0.125 & 0.2 & 0.5
\end{tabular}




\begin{tabular}{|c|c|c|c|}
\hline - Visual conditions & 1 & 1 & 1 \\
\hline Soil & 0.032 & 0.03 & 0.028 \\
\hline - Geology and geomorphology & 0.125 & 0.9 & 0.9 \\
\hline - Vibrations & 1 & 1 & 1 \\
\hline Soil conditions & 0.875 & 0.1 & 0.1 \\
\hline - Amount of soil (mass balance) & 1 & 1 & 1 \\
\hline Nature & 0.105 & 0.377 & 0.324 \\
\hline Fauna & 0.2 & 0.5 & 0.75 \\
\hline - Lost or ruined habitats & 1 & 1 & 1 \\
\hline Flora & 0.8 & 0.5 & 0.25 \\
\hline - Natura 2000-areas & 0.875 & 0.875 & 0.875 \\
\hline - Ecological links and ecosystem & 0.125 & 0.125 & 0.125 \\
\hline Material assets and archaeological heritage & 0.087 & 0.087 & 0.089 \\
\hline Archaeologic & 0.75 & 0.25 & 0.5 \\
\hline - Historical buildings and sites & 1 & 1 & 1 \\
\hline Materials and sensuous feelings & 0.25 & 0.75 & 0.5 \\
\hline - Noise (incl. compound noise) & 1 & 1 & 1 \\
\hline Air pollution and climate & 0.054 & 0.239 & 0.065 \\
\hline Air pollution & 0.143 & 0.25 & 0.833 \\
\hline - Local air pollution & 1 & 1 & 1 \\
\hline Climate & 0.857 & 0.75 & 0.167 \\
\hline - Greenhouse gasses & 1 & 1 & 1 \\
\hline Water & $\mathbf{0 . 0 3 7}$ & 0.168 & 0.028 \\
\hline Surface water & 0.5 & 0.5 & 0.5 \\
\hline - Streams, lakes and other wetlands & 1 & 1 & 1 \\
\hline Groundwater & 0.5 & 0.5 & 0.5 \\
\hline - Lowering of groundwater level & 1 & 1 & 1 \\
\hline Population & 0.576 & 0.04 & 0.284 \\
\hline
\end{tabular}




\begin{tabular}{llll} 
Economic impacts & 0.207 & 0.066 & 0.045 \\
- Local and state finances & 0.9 & 0.2 & 0.1 \\
- Agriculture & 0.1 & 0.8 & 0.9 \\
Social impacts & 0.049 & 0.785 & 0.598 \\
- Small urban communities & 0.5 & 0.5 & 0.5 \\
- Outdoor and recreational activities & 0.5 & 0.5 & 0.5 \\
Transport & 0.743 & 0.149 & 0.357 \\
- Capacity & 0.134 & 0.056 & 0.134 \\
- Delay & 0.205 & 0.056 & 0.205 \\
- Accessibility & 0.481 & 0.071 & 0.481 \\
- Barrier effects & 0.03 & 0.269 & 0.03 \\
- Freight transport & 0.094 & 0.034 & 0.094 \\
- Public transport & 0.055 & 0.515 & 0.055 \\
\hline
\end{tabular}

The MCDA results should be clearly presented in the EIA, e.g. using a figure such as Figure 13, which illustrates the results from the case-study in form of total values ${ }^{5}$. Observing this figure, one can conclude that a project that simultaneously meets the demands of all profiles cannot be found.

Highway M5, Highway M51/2 and the Railway in corridor 5 perform well in the political profile but poorly in the other profiles. Highway M4, the combined ITS solution and the Harbour tunnel seems to perform relatively well in the sustainability and local profile. However, it is important to note that the assessments are associated with uncertainty, and should in real life testing be supplemented with additional examinations in form of e.g. economic and/or financial appraisal before any alternative is selected or deselected.

\footnotetext{
${ }^{5}$ The total value for each alternative is calculated using the additive value function model.
} 


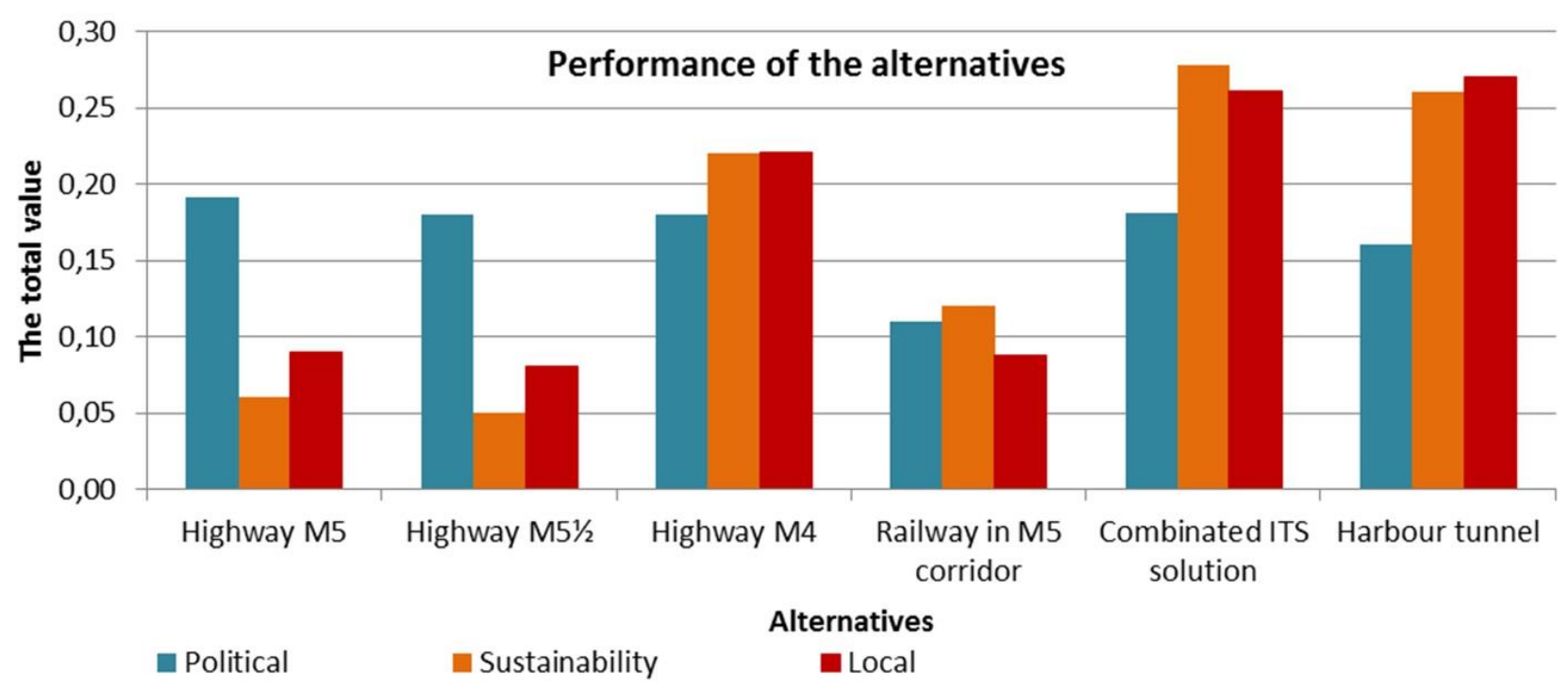

[Figure 13. Performance of alternatives in the three profiles]

\section{Discussion}

The review of the Swedish and UK assessment processes has shown that intervention-specific objectives are used to ensure that the projects comply with the needs, and that the generated alternatives can conform to those needs. The objectives are based on national transport policy visions to ensure that a project is in line with other national and international transport projects. In Denmark, no explicitly formulated national transport policy visions exist, which make is difficult to specify and formulate the politically desirable objectives on the three levels.

This paper propose a revision of the current Danish transport assessment process to include stakeholders with the purpose of improving the decision support. Presenting different output scenarios requires extra resources, and when the output has to cover all alternatives (including those that do not require EIA) the extra costs are somewhat significant. Hence, to ensure that the proposed revision can be realised, it is of major importance that only the impacts found relevant to assess for each case individually are included. 
The proposed impact overview table (see Table 4) is not in any sense a final list, and the table only provides a current overview. When applied, the impacts should be carefully reviewed to clarify whether any additional relevant project-specific impacts should be included.

The presented AHP tool is proposed to complement the existing socio-economic assessment in the Danish assessment process. AHP can be applied at workshops to initiate useful group discussions about the relative importance of the impacts, and to ensure that the "best" alternatives are selected.

The weights of the impacts can reflect the different stakeholder profiles (as described in the case-study) to illustrate different worldviews in the society. Potentially stakeholders have different preferences and prioritisations of impacts, and it may be difficult to divide the stakeholders into a set of respective profiles. To meet all interests major priorities and profiles may be needed. However, not to induce confusion, the number of profiles presented to the public should be reduced to retain the communicative value of the profiles. The profiles should simply create transparency to the output of the assessments, and help readers understand the political dilemmas and thereby easier accept recommendations and political decisions.

The Ministry of Transport is the overall top authority of EIA in Denmark, but the practising EIA authority depends on the intervention at hand. Rail Net Denmark carries out EIA studies for Danish Rail projects, The Danish Road Directorate is the authority if the project involves government owned roads, and affected municipalities are EIA authorities for minor transport projects (DME, 2015). Thus, the question is: who is to be the authority of an EIA if different types of transport modes and projects with different size and costs are to be examined by the same EIA? 
In Sweden, the majority of the different transport areas are grouped under Trafikverket ${ }^{6}$, and therefore, they do not have to deal with such a question. Instead of merging the Danish transport authorities, a working group comprised of employees from the involved authorities could be set to overview the EIA as a team.

\section{Conclusion and perspective}

In Danish EIAs, a long range of impacts are evaluated and described in long, and text-heavy, reports that are randomly structured. The findings for the conventional, monetary impacts are well described and carefully illustrated, whereas the more strategic, non-monetary impacts are only described qualitatively with only little or no illustrations or summaries attached. The corresponding process in Sweden is clearly structured, and all impacts are assessed systematically and transparent. As a result of this the findings become easier to verify and audit. In the UK, the verifiability and auditability come from the systematic use of comparison tables for the impacts and performance of the different alternatives. As in Sweden, the many UK guidelines for EIA require that the methods are used systematically and that they are clearly structured. Finally, intervention-specific objectives are stated early in the process based on stakeholder involvement, and used to generate and improve alternatives. Only those alternatives that can comply with the objectives, alone or in combination with other alternatives, are selected.

A key concern in the Danish transport assessment process is to identify intervention-specific objectives and to assess only the most important impacts for the specific transport project. To support this, an overview table containing a list of potential relevant impacts has been proposed

\footnotetext{
${ }^{6}$ The Swedish Transport Administration (STA), responsible for the long-term planning of the transport system
} 
along with guidelines for the selection of impacts based on the stated objectives and explicit circumstances of the considered alternatives. Only the most important impacts are to be assessed to ensure simplicity and transparency.

In the proposed revision, the creation of a comprehensive decision support tool will ensure a broader assessment of the non-monetary impacts. As demonstrated by the case, the AHP technique is able to assess all relevant impacts of a project and provide easy interpretable results. To obtain maximum value of using the AHP, the assessments should ideally be based on discussions in groups of stakeholders, experts, etc. in a structured workshop format. A format involving e.g. Delphi techniques could also be a solution if an even broader set of stakeholders are to be included. Finally, all findings should be presented clearly by using figures and overview tables to increase transparency. In general, the output should be presented in a level of detail that enables different parties to contribute to the debate and make fully informed decisions.

Overall, this paper has proposed a first attempt to revise the Danish assessment process towards a more appropriate standard. Future research within this field should concentrate on further examinations of the Danish EIA and corresponding processes in other comparable countries. This will enable us to uncover the necessary methods and guidelines for a new and more holistic EIA framework for the Danish transport sector.

\section{Acknowledgements}

The authors would like to express their gratitude to the Danish Road Directorate for interviews about the Danish EIA process. 


\section{References}

Barfod, M.B. (2018). Sustainable transport planning: involving stakeholders in the decision support process using planning workshops and MCDA. Transport, Vol. 33(4), Taylor \& Francis.

Barfod, M.B. (2012). Optimising Transport Decision Making using Customised Decision Models and Decision Conferences. PhD thesis, Department of Transport, Technical University of Denmark.

Barfod, M.B. and Salling, K.B. (2015). A new composite decision support framework for strategic and sustainable transport appraisals. Transportation Research Part A: Policy and Practice, Vol. 72, pp. 1-15, Elsevier.

Belton, V. and Stewart, T.J. (2002) Multi Criteria Decision Analysis: An Integrated Approach. Kluwer Academic Publishers, London.

Booz \& Co., and Temple. 2011. "HS2 London to the West Midlands Appraisal of Sustainability." CC and MF, City of Copenhagen and Mayor of Frederiksberg (2006). The City Ring (in Danish), VVM report and Environmental report, Copenhagen

Cornet, Y. (2016). Indicators and beyond: Assessing the sustainability of transport projects. PhD thesis, DTU Management Engineering, Technical University of Denmark.

Cornet, Y., Barradale, M.J., Gudmundsson, H. and Barfod, M.B. (2018). Engaging multiple actors in large-scale transport infrastructure project appraisal: an application of MAMCA to the case of HS2 high-speed rail. Journal of Advanced Transportation, Vol. 2018, Article ID 9267306.

Costanza, R.; D'Arge, R.; De Groot, R., et al. 1997. The value of the world's ecosystem services and natural capital. Nature, Vol. 387, pp. 253-260.

Daly, H. E. 1990. Toward some operational principles of sustainable development. Ecological Economics, Vol. 2, no. 1, pp. 1-6.

DME, Danish Ministry of Environment (2003). The profit of VVM - Evaluation of VVM in Denmark (in Danish), Main report

DRD, Danish Road Directorate (2010a). New Fixed Link at Frederikssund (in Danish), summary report, report 351

DRD, Danish Road Directorate (2010b). By-pass road abound Næstved (in Danish), summary report, report 365 . 
DRD, Danish Road Directorate (2011). The 3th fixed link across the Limfjord (in Danish), summary report, report 379

DRD, Danish Road Directorate (2014a). Fixed link across Storstrøm (in Danish), summary report, report 516

DRD, Danish Road Directorate (2014b). By-pass road abound Haderup (in Danish), summary report, report 509.

DRD, Danish Road Directorate (2015). By-pass road abound Ribe (in Danish), summary report, report 533.

DME, Danish Ministry of Environment (2015). Act. 1832: Assessment of the effects of certain public and private projects on the environment (in Danish), according to Danish law for planning

DMT, Danish Ministry of Transport (2015). Light-rail in Ring corridor 3 (in Danish), VVM report, Copenhagen

DTA, Danish Transport Agency (2009). Copenhagen - Ringsted project (in Danish), Environmental Report part 1, Copenhagen

GOV (2013). Guidance V: Appraisal tables of Department for Transport, London

Gudmundsson, H., Hall, R.P, Marsden, G., and Zietsman, J. (2015). Sustainable TransportationIndicators, Frameworks, and Performance Management, 1. Edition, Samfundslitteratur, Denmark, pp. 159

HS2 Ltd. 2013. "HS2 Phase One Environmental Statement: Documents." https://www.gov.uk/government/collections/hs2-phase-one-environmental-statementdocuments.

Jackson, L. E., Kurtz J.C. and Fisher W.S. (2000). Evaluation guidelines for ecological indicators. U.S. Environmental Protection Agency, Washington DC.

Joumard, R. and Gudmundsson, H. (2010). Indicators of Environmental Sustainability in Transport. Recherches.

Joumard, R. and Nicolas, J.P. (2010). “Transport Project Assessment Methodology within the Framework of Sustainable Development.” Ecological Indicators 10 (2): 136-42.

Leleur, S. (2012). Complex Strategic Choices: Applying Systemic Planning for Strategic Decision Making. Springer, London. 
NCHOD (2005). Compendium of Clinical and Health Indicators User Guide. National Centre for Health Out-comes Development (NCHOD), London School of Hygiene and Tropical Medicine, London.

Niemeijer D. (2002). Developing indicators for environmental policy: data-driven and theorydriven approaches examined by example. Environ. Sci. Policy, 5, 91-103.

Niemeijer D. and de Groot R.S. (2008). Conceptual framework for selecting environmental indicator sets. Ecological Indicators, vol 8, 14-25.

Marsden, Greg, Charlotte Kelly, and Carolyn Snell. 2006. "Selecting Indicators for Strategic Performance Management." Transportation Research Record: Journal of the Transportation Research Board, no. 1956 (January): 21-29.

MN and SC, Municipality of Nacka and Stockholm County (2014). Environmental Impact Assessment appurtenant road plan, road 222 Skurubron (in Swedish). Examination report, approved by the Swedish Transport Administration, Sundbyberg

Morris, P. and Therivel, R. (2001). Methods of Environmental Impact Assessment, 2. Edition, Spon Press, New York

MÄ and KC, Municipality of Älmhult and Kronoberg County (2011). Environemtal Impact Assessment appurtenant work plan for road 23 Älmhult-Växjö, part âlmhult-Ljungstorp and part Ljungstorp-Mölleryd (in Swedish). Examination report, approved by the Swedish Transport Administration, Jönköping

Olesen, I.M. (2016) Transport Infrastructure Assessment and EIA: Determination and integration of Environmental Impacts in a Socio-Economic Perspective. B.Eng thesis. Department of Transport, Technical University of Denmark.

Pryn, M.R., Cornet, Y. and Salling, K.B. (2015). Applying sustainability theory to transport infrastructure assessment using a multiplicative AHP Decision Support Model. Transport, Vol. 30, no. 3, pp. 330-341

RND and DNA, Rail Net Denmark and Danish Nature Agency (2014). Electrification and upgrading of speed limits, North of Køge - Næstved (in Danish). Final VVM report, Copenhagen

Saaty, T.L. (1977) Scenarios and priorities in transport planning: Application to the Sudan. Transport Research, 11, 343-350.

Salling, K.B. (2008). Assessment of Transport Projects: Risk Analysis and Decision Support. PhD thesis, Department of Transport, Technical University of Denmark 
SRA, The Swedish Rail Administration (2009). Environmental consequence description, railway report, Ostlänken section Norrköping C - Linköping C (in Swedish). Final report, Sundbyberg

STA, the Swedish Transport Administration (2013). Report, Railway plan Mälar track, TomtebodaHuvudstra, Municipality of Solna (in Swedish). Examination report, Spånga

The Engineer (2013). Femern ends with the largest VVM appraisals in Danish history, by Birgitte Marfelt

TAG, Transport Analysis Guidance (2014). The Transport Appraisal Process Department for Transport, Transport Appraisal and Strategic Modelling (TASM) Division, London

Tsamboulas, D.A. (2007) A tool for prioritizing multinational transport infrastructure investments. Transport Policy, 14, 11-26.

Vreeker, R., Nijkamp, P. and Welle, C.T. (2002) A multicriteria decision support methodology for evaluating airport expansion plans. Transportation Research Part D, 7, 27-47.

Wright, S., Nelson, J.D., Cooper, J.M. and Murphy, S. (2009). An evaluation of the transport to employment (T2E) scheme in Highland Scotland using social return on investment (SROI). Journal of Transport Geography, 17, 457-467.

Zietsman, J., Ramani, T.,Potter, J., Reeder, V. and DeFlorio, J. (2011). NCHRP REPORT 708 A Guidebook for Sustainability Performance Measurement for Transportation Agencies. Vol. 708. Transportation Research Board 


\section{Appendix $A^{7}$ Description of impacts}

\section{Landscape}

- Visual conditions: proportions, colours, view, screen enclosure, texture

- Sensuous feelings: Sound, smell, taste, touch

\section{Soil}

- Surface geology: Glacial sedimentation and depositing, glacial drift and rivers

- Underground geology: Previous surface formations. The type of sedimentation is important to the ability to bear a construction

- The immaterial history of Earth: Preservation, protection and administration of fossils, stratigraphy, minerals or additional geological interests

- Topography (terrain): Shape of landscape/terrain. Natural: E.g. abrasion, sedimentary depositing in streams. Humanrelated: E.g. visual aspects

- Vibrations: Can cause landslides or cause the effect of a small earthquake

\section{Nature}

- Pollution (incl. eutrophication): Physical and chemical environment effects such as atmospheric pollution or pollution of water

- Microorganisms underground: Conditions for insects that affect e.g. the ground quality

- Ecological links and ecosystem: Retention of opportunities for diversification for wild plants and animals

\section{Material assets and archaeological heritage}

- Historical areas: E.g. harbours, communities, bridges, rivers, gardens

- Noise (incl. compound noise): During construction and operating period. Compound noise e.g. from different transport modes for simultaneous constructions in the area

${ }^{7}$ Based on Morris and Therivel (2001) 
- Pressure on the labour market: Amount of labour during the construction period

\section{Air pollution and climate}

- Sulphur dioxide $\left(\mathrm{SO}_{2}\right)$ : Coal- and oil-fired power stations, industrial boilers, waste incinerators, domestic heating, diesel vehicles, metal smelters, paper manufacturing

- Particulates (dust, $\mathrm{PM}_{10}, \mathrm{PM}_{2.5}$ ): Coal- and oil-fired power stations, industrial boilers, waste incinerators, domestic heating, many industrial plants, diesel vehicles, construction, mining, quarrying, cement manufacturing

- Nitrogen oxides $\left(\mathrm{NO}_{\mathrm{x}}\right.$ : $\left.\mathrm{NO}, \mathrm{NO}_{2}\right)$ : Coal-, oil- and gas-fired power stations, industrial boilers, waste incinerators, motor vehicles

- Carbon monoxide (CO): Motor vehicles, fuel combustion

- Volatile organic compounds (VOCs), e.g. benzene: Petrol-engine vehicle exhausts, leakage at petrol stations, paint manufacturing

- Toxic organic micropollutants (TOMPs), e.g. PAHs, PCBs: Waste incinerators, coke production, coal combustion - Toxic metals, e.g. lead: Vehicle exhausts (leaded petrol), metal processing, waste incinerators, oil and coal combustion, battery manufacturing, cement and fertiliser production

- Toxic chemicals, e.g. chlorine: Chemical plants, metal processing, fertiliser manufacturing

- Ozone $\left(\mathrm{O}_{3}\right)$ : Secondary pollutant formed form VOCs and nitrogen oxides

- Ionising radiation (radionuclides): Nuclear reactors and waste storage, some medical facilities

- Greenhouse gasses: $\mathrm{CO}_{2}$ : fuel combustion, especially power stations; $\mathrm{CH}_{4}$ : coal mining, gas leakage, landfill sites - Alterations to the airflow: E.g. around large structures such as office blocks, multi-storey car parks and shopping arcades, causing wind turbulence which affects the comfort and sometimes the safety of pedestrians.

- Addition of moisture from industrial cooling towers, reservoirs: Can cause an increased frequency of fog or even icing on nearby roads

- Ponding of cold air behind physical barriers: This could be e.g. roads and railway bankments that cause increasing incidence of frost which can damage agriculture and horticultural crops in the area

\section{Water}

- Streams, lakes and other wetlands: Velocity, size and tempering of water systems, change in water flow, composition of sediments, stability and shape of base (abrasion) 
- Hydraulic systems: Hydraulic systems includes sub-systems (sewerage, drain pipes, etc.) and ecosystems that is affected by the local climate

- Recreational value: Sailing, bathing beach, harbours, etc.

- Infiltration and water flow at land: Opportunity for the water to infiltrate to the ground and the consequences of too much water in the ground (that cannot infiltrate immediately)

- Pollution of surface water: Changes of quality due to e.g. chemical and organic pollution, changes of content of oxygen, haziness, changes in $\mathrm{pH}$ and waste

- Human related: Changes risk of flooding or changes regulation

- Water quality: Changes in quality due to e.g. chemical and organic pollution or movement of polluted water

- Lowering of groundwater level: Reduced flow of water in streams due to lowering of groundwater

- Influence from buildings: Buildings that is inadequately foundered.

\section{Population}

- Characteristics of employment: Professions in the area

- Change in other population characteristics: Family size, income level, socio-economic groups, sex, age, employment, etc.

- Settlement patterns: Homelessness and additional housing problems

- Health services; social support: Education, police, fire stations, health- and social sector

- Social problems: Crime, stress, integration, diseases and parting

- Traffic management systems: Signs or other techniques using intelligent transport systems (ITS) 